\title{
From Racemic Units to Polar Materials
}

\author{
Romain Gautier, ${ }^{\dagger}$ Alexander J. Norquist, ${ }^{\ddagger}$ and Kenneth R. Poeppelmeier ${ }^{* \dagger}$ \\ ${ }^{\dagger}$ Department of Chemistry, Northwestern University, 2145 Sheridan Road, Evanston, Illinois 60208-3113, United States \\ ${ }^{\ddagger}$ Department of Chemistry, Haverford College, 370 Lancaster Avenue, Haverford, Pennsylvania 19041, United States
}

\section{Supporting Information}

ABSTRACT: A new route is described that enables the design of polar materials using racemic basic building units (BBUs). $\Lambda$ - and $\Delta-\left[\mathrm{Cu}\left(\mathrm{H}_{2} \mathrm{O}\right)(\mathrm{bpy})_{2}\right]^{2+}$ complexes in noncentrosymmetric $\left[\mathrm{Cu}\left(\mathrm{H}_{2} \mathrm{O}\right)(\mathrm{bpy})_{2}\right]_{2}\left[\mathrm{HfF}_{6}\right]_{2} \cdot 3 \mathrm{H}_{2} \mathrm{O}$ and centrosymmetric $\left[\mathrm{Cu}\left(\mathrm{H}_{2} \mathrm{O}\right)(\mathrm{bpy})_{2}\right]\left[\mathrm{BF}_{4}\right]_{2}$ reveal that racemic BBUs in the solid state can lead directly to noncentrosymmetry. The structure is polar if only mirror or glide planes relate the left- and right-handed enantiomers, whereas nonpolar, achiral structures result if rotoinversion relates the left- and right-handed enantiomers. This structural analysis also provides an alternative route in the design of polar materials that had always been engineered from polar BBUs.

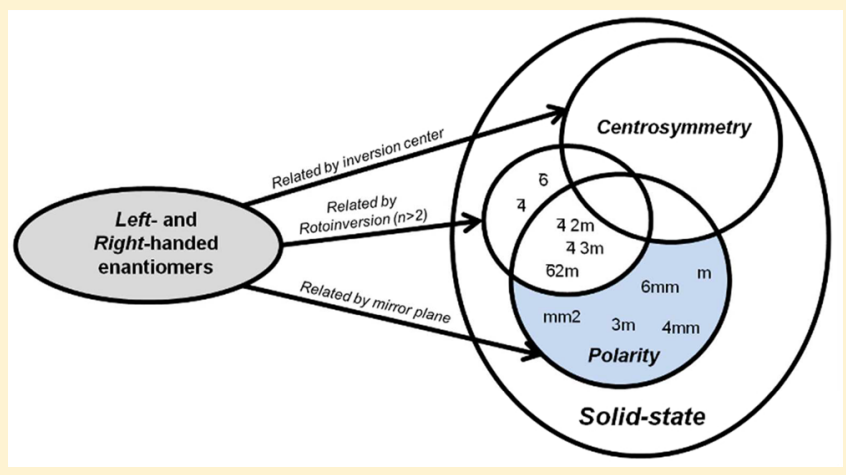

\section{INTRODUCTION}

Chiral basic building units (BBUs) are of interest owing to their role in the synthesis of noncentrosymmetric chiral materials. Thus, the ability of BBUs with a unique handedness to crystallize into chiral materials is extensively used in organic and inorganic chemistry. ${ }^{1,2}$ Similarly, polar BBUs have been used to synthesize polar materials, but their arrangement remains difficult to predict. ${ }^{3-7}$ To improve control over the alignment of polar BBUs, several authors have recently reported the addition of chiral BBUs as a means of preventing the antiparallel alignment of polar BBUs. ${ }^{8-13}$ The polarity, however, cannot be guaranteed, as chiral, nonpolar structures can result (Figure 1).

The crystallization of racemates into chiral space groups is extremely rare. Two cases can be distinguished: (i) the resolution of the two chiral structures into distinct enantiomorphs (chiral resolution) or into twin domains (racemic twins) and (ii) the observation of both racemates as crystallographically independent groups in a single chiral structure (called kryptoracemates). Dalhus et al. identified 17 kryptoracemates (4 chiral, 13 polar chiral) in the Cambridge Structural Database (CSD), whereas approximately 11500 racemates were identified in a centrosymmetric space group. ${ }^{14}$ In a more recent work, Fábián et al. estimated the proportion of kryptoracemates to be " $0.1 \%$ of all organic structures". 15 A search of the CSD using the string "racemic" and "racemate" returns 2140 structures of racemic compounds of which 329 (about 15\%) are polar and nonchiral and 32 (about $1.5 \%$ ) are noncentrosymmetric, nonpolar, and nonchiral. These numbers are probably underestimated, ${ }^{14}$ but an interesting feature can be revealed: The loss of inversion symmetry in racemate compounds will not likely lead to the chiral space groups; other achiral noncentrosymmetric space groups such as polar space groups are far more common.
Despite the obvious importance of this feature, the role of racemic BBUs in polarity in the solid state has not been investigated. Here, we present a study of a racemic mixture of the same chiral cations that can crystallize into either a centrosymmetric structure or a polar, achiral structure.

\section{EXPERIMENTAL SECTION}

Synthesis. $\left[\mathrm{HfF}_{6}\right]_{2}\left[\mathrm{Cu}\left(\mathrm{H}_{2} \mathrm{O}\right)(\text { bpy })_{2}\right]_{2} \cdot 3 \mathrm{H}_{2} \mathrm{O}$ crystals were synthesized by hydrothermal synthesis. A mixture of $\mathrm{HfO}_{2}(1.69 \mathrm{mmol})$, $\mathrm{CuO}$ (1.69 mmol), 2,2'-bipyridine (2.56 mmol), 48\% HF (27.8 $\mathrm{mmol})$, and deionized $\mathrm{H}_{2} \mathrm{O}(5.5 \mathrm{mmol})$ was added to a Teflon pouch. The heat-sealed pouches were placed in a $125 \mathrm{~mL}$ Parr autoclave with $40 \mathrm{~mL}$ of distilled water, heated to $150{ }^{\circ} \mathrm{C}$ for $24 \mathrm{~h}$, and cooled to room temperature at the rate of $6{ }^{\circ} \mathrm{C} / \mathrm{h}$. Blue crystals were recovered by filtration under vacuum.

Single-Crystal X-ray Diffraction. Single-crystal X-ray diffraction analyses were performed in a Bruker-APEX II CCD diffractometer at $100(2) \mathrm{K}$. The crystal-to-detector distance was $60 \mathrm{~mm}$, and data integration was achieved using the SAINT-PLUS program. ${ }^{16}$ Absorption corrections were applied with SADABS. ${ }^{17}$ The structures were determined by direct methods, completed by Fourier difference syntheses with SIR97, ${ }^{18}$ and refined using SHELXL-97. ${ }^{19}$ No highersymmetry or unit cells were found upon examination with the program PLATON. ${ }^{20}$ The $\left[\mathrm{HfF}_{6}\right]_{2}\left[\mathrm{Cu}\left(\mathrm{H}_{2} \mathrm{O}\right)(\text { bpy })_{2}\right]_{2} \cdot 3 \mathrm{H}_{2} \mathrm{O}$ structure crystallizes in the space group Pna2 $2_{1}$ (No. 33) with the unit-cell parameters $a$ $=20.5420(8) \AA, b=14.8692(5) \AA$, and $c=15.0844(6) \AA$. The final agreement factors are $\mathrm{R} 1=0.052, \mathrm{wR} 2=0.14$, and $\mathrm{GoF}=1.09$.

\section{RESULTS AND DISCUSSION}

$\left[\mathrm{Cu}\left(\mathrm{H}_{2} \mathrm{O}\right)(\mathrm{bpy})_{2}\right]_{2}\left[\mathrm{HfF}_{6}\right]_{2} \cdot 3 \mathrm{H}_{2} \mathrm{O}$ was synthesized under mild hydrothermal conditions, single-crystal $\mathrm{X}$-ray diffraction data were collected, and a noncentrosymmetric polar structure was

Received: October 19, 2012

Published: November 6, 2012 


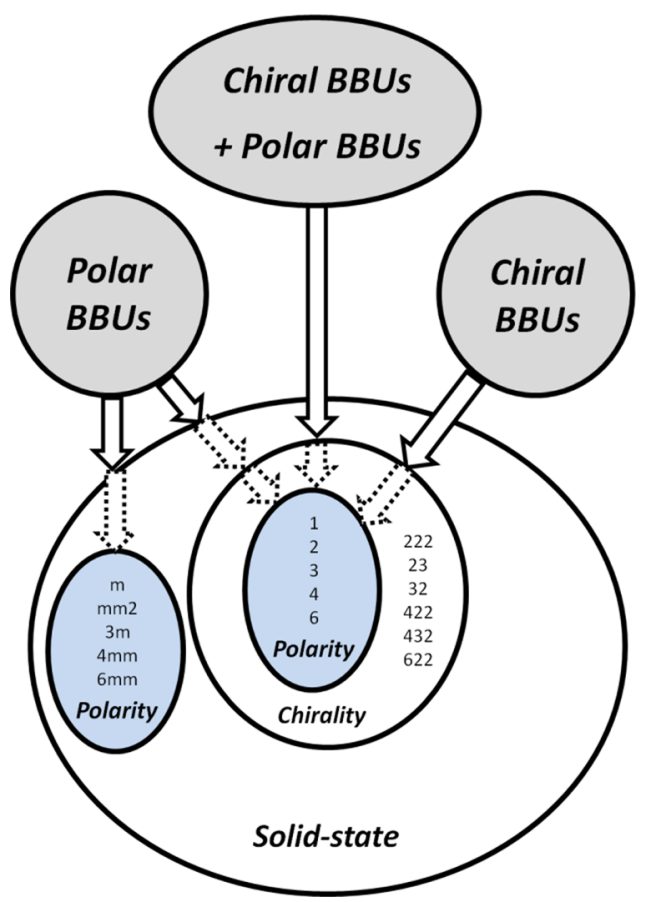

Figure 1. Polar and chiral crystal classes targeted in the solid state from polar BBUs, chiral BBUs, or a combination of polar BBUs and chiral BBUs. Chiral BBUs must crystallize in a chiral space group (solid arrows). Polar BBUs might crystallize in a polar space group (dashed arrows).

determined (space group $P n a 2_{1}$, crystal class $m m 2$ ) (Figure 2a). To our knowledge, $\left.\left[\mathrm{Cu}(\mathrm{bpy})_{2} \mathrm{H}_{2} \mathrm{O}\right)\right]\left[\mathrm{BF}_{4}\right]_{2}$ is the only reported structure with $\left[\mathrm{Cu}\left(\mathrm{H}_{2} \mathrm{O}\right)(\mathrm{bpy})_{2}\right]^{2+}$ cations and fluoride anions in the CSD. ${ }^{21}$ This structure crystallizes in the centrosymmetric space group $P 2_{1} / c$ (Figure $2 b$ ). Owing to $\pi-\pi$ interactions between the bipyridine ligands, the $[\mathrm{Cu}-$ $\left.\left(\mathrm{H}_{2} \mathrm{O}\right)(\text { bpy })_{2}\right]^{2+}$ cations create layers that stack along the $a$ axis in both structures. The stereochemistry of the $\left[\mathrm{Cu}\left(\mathrm{H}_{2} \mathrm{O}\right)\right.$ (bpy $\left.)_{2}\right]^{2+}$ cations is described by the $\Delta$ and $\Lambda$ enantiomers, which are related by symmetry (Figure 3$)^{22}$

The two structures differ in the nature of the anions and the geometries of the layers. The $\left[\mathrm{BF}_{4}\right]^{-}$anions are both smaller (B-F bond lengths ranging between $1.307(7)$ to $1.397(7) \AA$ ) and more numerous (two $\left[\mathrm{BF}_{4}\right]^{-}$per $\left[\mathrm{Cu}\left(\mathrm{H}_{2} \mathrm{O}\right)(\mathrm{bpy})_{2}\right]^{2+}$ ) than the $\left[\mathrm{HfF}_{6}\right]^{2-}$ anions. The $\mathrm{Hf}-\mathrm{F}$ bonds range between $1.929(6)$ and $2.010(5) \AA$, and a 1: 1 ratio is observed between $\left[\mathrm{HfF}_{6}\right]^{2-}$ and $\left[\mathrm{Cu}\left(\mathrm{H}_{2} \mathrm{O}\right)(\mathrm{bpy})_{2}\right]^{2+}$ in $\left[\mathrm{Cu}\left(\mathrm{H}_{2} \mathrm{O}\right)-\right.$ $\left.(\mathrm{bpy})_{2}\right]_{2}\left[\mathrm{HfF}_{6}\right]_{2} \cdot 3 \mathrm{H}_{2} \mathrm{O}$. This difference directly affects the distance between copper centers in these compounds and the orientations of the $\left[\mathrm{Cu}\left(\mathrm{H}_{2} \mathrm{O}\right)(\mathrm{bpy})_{2}\right]^{2+}$ cations. The nearest $\mathrm{Cu}-\mathrm{Cu}$ distance in $\left[\mathrm{Cu}\left(\mathrm{H}_{2} \mathrm{O}\right)(\mathrm{bpy})_{2}\right]_{2}\left[\mathrm{HfF}_{6}\right]_{2} \cdot 3 \mathrm{H}_{2} \mathrm{O}$ is 5.7071(13) $\AA$, versus 8.2031(11) $\AA$ in $\left.\left[\mathrm{Cu}\left(\mathrm{H}_{2} \mathrm{O}\right)(\mathrm{bpy})_{2}\right)\right]$ $\left[\mathrm{BF}_{4}\right]_{2}$. The short $\mathrm{Cu}-\mathrm{Cu}$ distances in $\left[\mathrm{Cu}\left(\mathrm{H}_{2} \mathrm{O}\right)\right.$ (bpy $\left.)_{2}\right]_{2}\left[\mathrm{HfF}_{6}\right]_{2} \cdot 3 \mathrm{H}_{2} \mathrm{O}$ are found in $\Delta-\Delta$ and $\Lambda-\Lambda$ dimers, in which two distinct $\pi-\pi$ interactions are observed. Layers are built from chains of $-\Delta \mathrm{d}-\Lambda \mathrm{u}-\Delta \mathrm{d}-\Lambda \mathrm{u}-$ enantiomers $(\mathrm{u}=\mathrm{up}$ and $\mathrm{d}=$ down describe the orientation of the cation along the $b$ axis) in $\left.\left[\mathrm{Cu}\left(\mathrm{H}_{2} \mathrm{O}\right)(\mathrm{bpy})_{2}\right)\right]\left[\mathrm{BF}_{4}\right]_{2}$, whereas both $-\Delta \mathrm{u}-\Lambda \mathrm{d}-$ $\Delta \mathrm{u}-\Lambda \mathrm{d}-$ and $-\Delta \mathrm{d}-\Lambda \mathrm{u}-\Delta \mathrm{d}-\Lambda \mathrm{u}-$ chains are present in $\left[\mathrm{Cu}\left(\mathrm{H}_{2} \mathrm{O}\right)(\text { bpy })_{2}\right]_{2}\left[\mathrm{HfF}_{6}\right]_{2} \cdot 3 \mathrm{H}_{2} \mathrm{O}$ (Figure 4).

The presence of similar chains in both structures can be explained by the optimization of $\pi-\pi$ interactions between bpy ligands. To stabilize these interactions, the planes of bpy ligands (a)

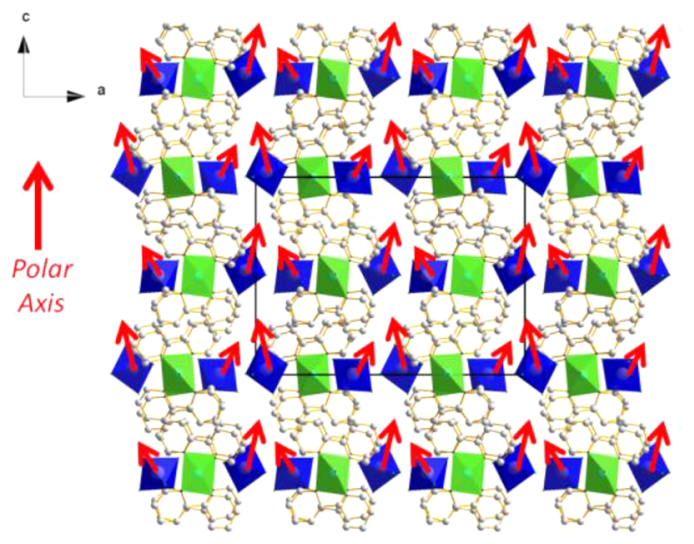

s

(b)

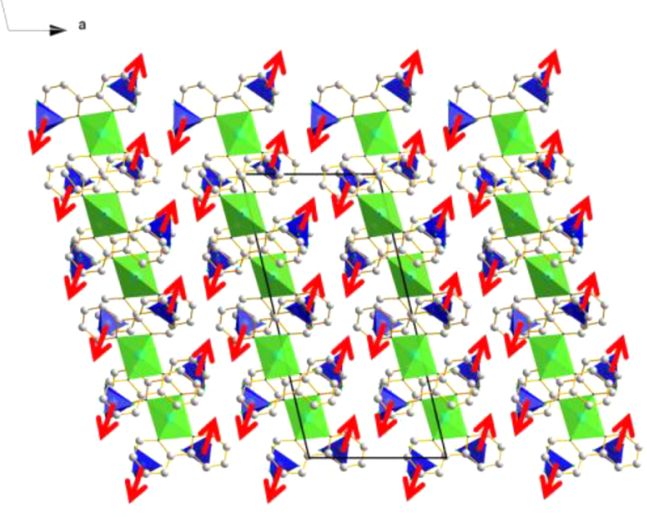

Figure 2. Views of (a) $\left[\mathrm{Cu}\left(\mathrm{H}_{2} \mathrm{O}\right)(\mathrm{bpy})_{2}\right]_{2}\left[\mathrm{HfF}_{6}\right]_{2} \cdot 3 \mathrm{H}_{2} \mathrm{O}$ and (b) $\left.\left[\mathrm{Cu}\left(\mathrm{H}_{2} \mathrm{O}\right)(\mathrm{bpy})_{2}\right)\right]\left[\mathrm{BF}_{4}\right]_{2}$ along layers built from $\left[\mathrm{Cu}\left(\mathrm{H}_{2} \mathrm{O}\right)(\mathrm{bpy})_{2}\right]^{2+}$ cations. Blue and green octahedra represent $\left[\mathrm{HfF}_{6}\right]^{2-}$ or $\left[\mathrm{BF}_{4}\right]^{-}$anions and $\left[\mathrm{Cu}\left(\mathrm{H}_{2} \mathrm{O}\right)(\text { bpy })_{2}\right]^{2+}$ cations, respectively. The water molecules in structure $\left[\mathrm{Cu}\left(\mathrm{H}_{2} \mathrm{O}\right)(\mathrm{bpy})_{2}\right]_{2}\left[\mathrm{HfF}_{6}\right]_{2} \cdot 3 \mathrm{H}_{2} \mathrm{O}$ have been removed for clarity. Red arrows represent the distortion of the anions.

of successive aligned cations must be parallel or perpendicular, which is achieved through an alternation of the $\Delta$ and $\Lambda$ enantiomers. ${ }^{23}$ Moreover, the angle between the copper cation and the two bpy ligands is $150.6^{\circ}$ because of the repulsion with the water ligand (Figure 3 ). For this reason, the alternation of both the handedness $(\Delta$ and $\Lambda)$ and the direction ( $\mathrm{u}=\mathrm{up}$ and $\mathrm{d}=$ down) such as $-\Delta \mathrm{d}-\Lambda \mathrm{u}-\Delta \mathrm{d}-\Lambda \mathrm{u}-$ or $-\Delta \mathrm{u}-\Lambda \mathrm{d}-$ $\Delta \mathrm{u}-\Lambda \mathrm{d}-$ allows for the optimization of the $\pi-\pi$ interactions (Figure S1, Supporting Information).

Two different stacking sequences of these layers are observed in $\left.\left[\mathrm{Cu}\left(\mathrm{H}_{2} \mathrm{O}\right)(\mathrm{bpy})_{2}\right)\right]\left[\mathrm{BF}_{4}\right]_{2}$ and $\left[\mathrm{Cu}\left(\mathrm{H}_{2} \mathrm{O}\right)-\right.$ (bpy $\left.)_{2}\right]_{2}\left[\mathrm{HfF}_{6}\right]_{2} \cdot 3 \mathrm{H}_{2} \mathrm{O}$ (Figure 5). In $\left.\left[\mathrm{Cu}\left(\mathrm{H}_{2} \mathrm{O}\right)(\text { bpy })_{2}\right)\right]-$ $\left[\mathrm{BF}_{4}\right]_{2}$, the layers of $\left.\left[\mathrm{Cu}\left(\mathrm{H}_{2} \mathrm{O}\right)(\text { bpy })_{2}\right)\right]^{2+}$ align along the $a$ axis, creating centers of inversion between adjacent layers that reverse the handedness of the racemic building units. In contrast, layer translations are observed in $\left[\mathrm{Cu}\left(\mathrm{H}_{2} \mathrm{O}\right)\right.$ (bpy $\left.)_{2}\right]_{2}\left[\mathrm{HfF}_{6}\right]_{2} \cdot 3 \mathrm{H}_{2} \mathrm{O}$ that preclude inversion symmetry between enantiomers (Figure 5 ). These translations are derived from the hydrogen-bonding interactions within this compound. The fluoride anions in $\left[\mathrm{Cu}\left(\mathrm{H}_{2} \mathrm{O}\right)(\mathrm{bpy})_{2}\right]_{2}\left[\mathrm{HfF}_{6}\right]_{2} \cdot 3 \mathrm{H}_{2} \mathrm{O}$ are more nucleophilic than those in $\left.\left[\mathrm{Cu}\left(\mathrm{H}_{2} \mathrm{O}\right)(\text { bpy })_{2}\right)\right]\left[\mathrm{BF}_{4}\right]_{2}$, the result of a decreased $\mathrm{Hf}-\mathrm{F}$ bond strength compared to the strength of $\mathrm{B}-\mathrm{F}$ bonds in $\left[\mathrm{BF}_{4}\right]^{-}$. This increase in fluoride- 


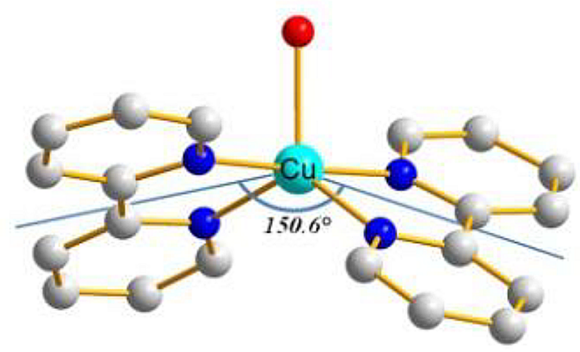

$4-\left[\mathrm{Cu}\left(\mathrm{H}_{2} \mathrm{O}\right)(\mathrm{bpy})_{2}\right]^{2+}$

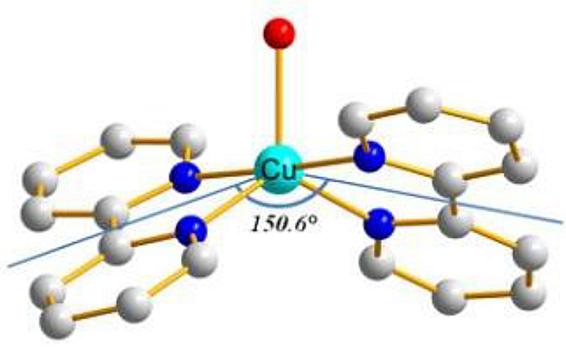

$A-\left[\mathrm{Cu}\left(\mathrm{H}_{2} \mathrm{O}\right)(\mathrm{bpy})_{2}\right]^{2+}$

Figure 3. Representation of the $\Delta$ - and $\Lambda$ - $\left[\mathrm{Cu}\left(\mathrm{H}_{2} \mathrm{O}\right)(\mathrm{bpy})_{2}\right]^{2+}$ enantiomers with $\mathrm{C}_{2}$ symmetry.

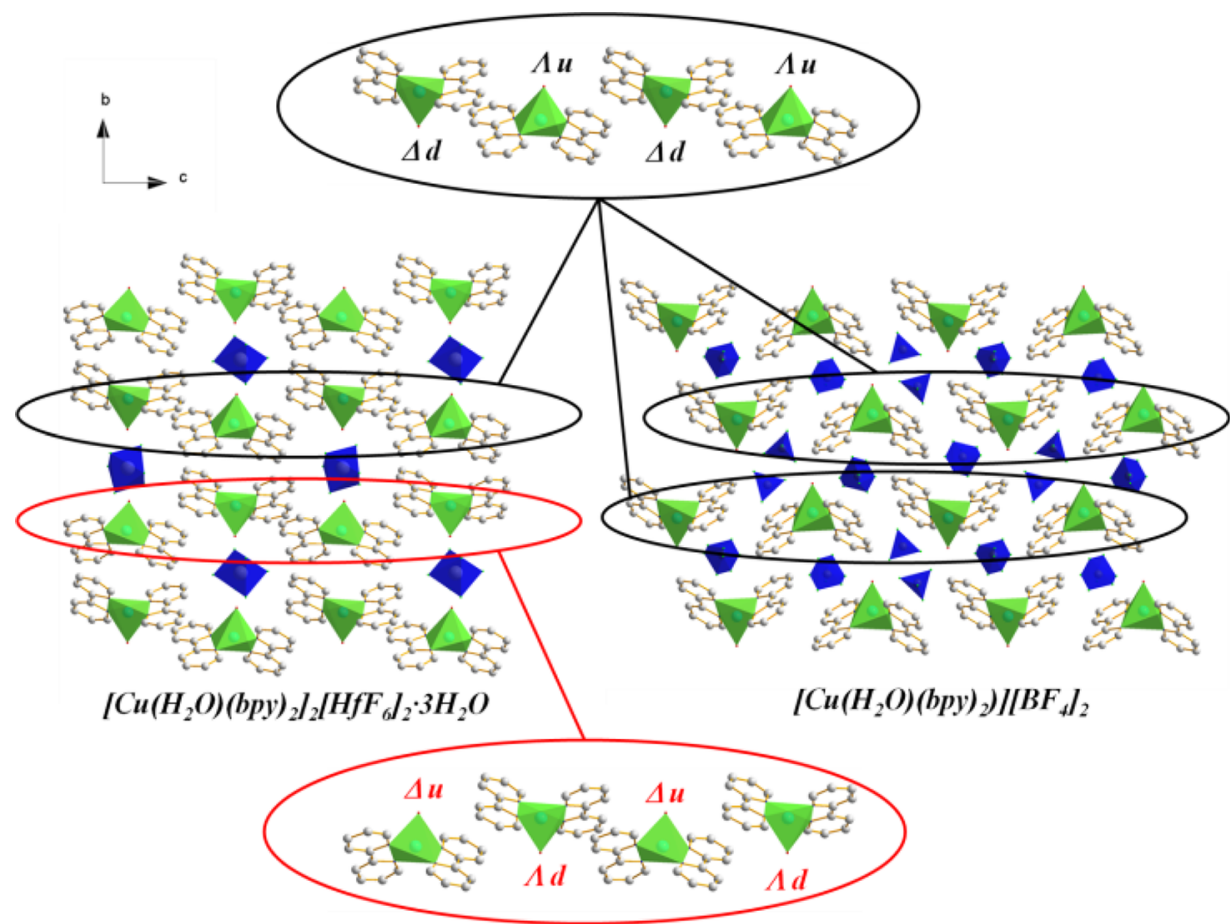

Figure 4. Layers of $\Delta-/ \Lambda-\left[\mathrm{Cu}\left(\mathrm{H}_{2} \mathrm{O}\right)(\text { bpy })_{2}\right]^{2+}$ enantiomers in $\left[\mathrm{Cu}\left(\mathrm{H}_{2} \mathrm{O}\right)(\text { bpy })_{2}\right]_{2}\left[\mathrm{HfF}_{6}\right]_{2} \cdot 3 \mathrm{H}_{2} \mathrm{O}$ and $\left.\left[\mathrm{Cu}\left(\mathrm{H}_{2} \mathrm{O}\right)(\mathrm{bpy})_{2}\right)\right]\left[\mathrm{BF}_{4}\right]_{2}$. The cation complexes pack through $\pi-\pi$ stacking of the $2,2^{\prime}$-bipyridine ligands. $\left[\mathrm{HfF}_{6}\right]^{2-}$ or $\left[\mathrm{BF}_{4}\right]^{-}$anions occupy the cavities formed by the $\Delta-/ \Lambda$ $\left[\mathrm{Cu}\left(\mathrm{H}_{2} \mathrm{O}\right)(\text { bpy })_{2}\right]^{2+}$ units. The letters $\mathrm{d}$ and $\mathrm{u}$ within $\Delta \mathrm{d}, \Delta \mathrm{u}, \Lambda \mathrm{d}$, and $\Lambda \mathrm{u}$ indicate the orientation of the $\left[\mathrm{Cu}\left(\mathrm{H}_{2} \mathrm{O}\right)(\mathrm{bpy})_{2}\right]^{2+}$ cation: $\mathrm{u}$ for up $[\mathrm{Cu}-$ $\left(\mathrm{H}_{2} \mathrm{O}\right)$ bond along the $+b$ axis] and $\mathrm{d}$ for down $\left[\mathrm{Cu}-\left(\mathrm{H}_{2} \mathrm{O}\right)\right.$ bond along the $-b$ axis].

anion nucleophilicity promotes the inclusion of water molecules in $\left[\mathrm{Cu}\left(\mathrm{H}_{2} \mathrm{O}\right)(\mathrm{bpy})_{2}\right]_{2}\left[\mathrm{HfF}_{6}\right]_{2} \cdot 3 \mathrm{H}_{2} \mathrm{O}$, in order to stabilize the underbonded fluoride anions. Three water molecules are required per formula unit to bridge between successive $\left[\mathrm{HfF}_{6}\right]^{-}$groups, owing to the distance between $\mathrm{Hf}$ centers $[14.8692(6) \AA]$. An extensive two-dimensional hydrogen-bonding network is observed between the bound and occluded water molecules and $\left[\mathrm{HfF}_{6}\right]^{2-}$ anions. The occluded water molecules "bridge" between adjacent $\left[\mathrm{HfF}_{6}\right]^{2-}$ anions, which adopt a staggered geometry that precludes inversion symmetry that would reverse the handedness of $\left[\mathrm{Cu}\left(\mathrm{H}_{2} \mathrm{O}\right)\right.$ $\left.(\mathrm{bpy})_{2}\right]^{2+}$ cations of different layers. Secondary distortions are present in both the $\left[\mathrm{HfF}_{6}\right]^{2-}$ and $\left[\mathrm{BF}_{4}\right]^{-}$ions, as a result of hydrogen-bonding interactions. ${ }^{24}$ The distortions within the $\left[\mathrm{HfF}_{6}\right]^{2-}$ anions roughly align along the $c$ axis in $\left[\mathrm{Cu}\left(\mathrm{H}_{2} \mathrm{O}\right)\right.$ (bpy $\left.)_{2}\right]_{2}\left[\mathrm{HfF}_{6}\right]_{2} \cdot 3 \mathrm{H}_{2} \mathrm{O}$, whereas complete cancellation is observed in the $\left[\mathrm{BF}_{4}\right]^{-}$anions in $\left.\left[\mathrm{Cu}(\mathrm{bpy})_{2} \mathrm{H}_{2} \mathrm{O}\right)\right]\left[\mathrm{BF}_{4}\right]_{2}$ (Figure 2).
To relate symmetrically left- and right-handed enantiomers, improper symmetry operations must be considered. Three improper symmetry operations exist: the mirror plane $\left(S_{1}\right)$, the inversion center $\left(S_{2}\right)$, and the rotoinversion $\left(S_{n}\right.$ with $\left.n>2\right)$. As mentioned above, kryptoracemates, which are materials exhibiting crystallographically independent racemates, are extremely rare. For this reason, at least one improper operation is usually generated by the packing in the solid state to relate symmetrically both left- and right-handed enantiomers. If the structure is centrosymmetric, the inversion center relates the left- and right-handed enantiomers. If the structure is noncentrosymmetric but nonchiral and nonpolar, rotoinversions relate the enantiomers [five crystal classes: $\overline{6}\left(C_{3 h}\right), \overline{4}\left(S_{4}\right)$, $\overline{4} 2 m\left(D_{2 d}\right), \overline{4} 3 m\left(T_{d}\right)$, and $\left.\overline{6} 2 m\left(D_{3 h}\right)\right]$. If the structure is polar, the mirror (or glide) plane is the unique improper operation relating the left- and right-handed enantiomers (Figure 6). Only five crystal classes, among the 10 polar crystal classes, are achiral: $m\left(C_{s}\right), m m 2\left(C_{2 v}\right), 3 m\left(C_{3 v}\right), 4 m m\left(C_{4 v}\right)$, and $6 m m$ $\left(C_{6 v}\right){ }^{25}$ Moreover, these five classes are also the only ones 


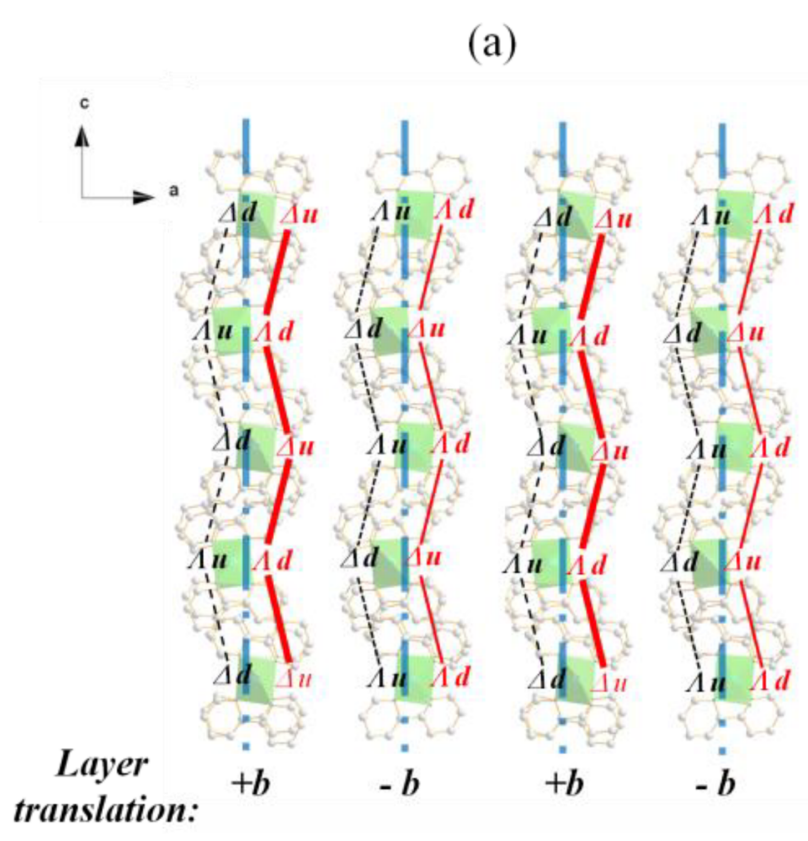

(b)

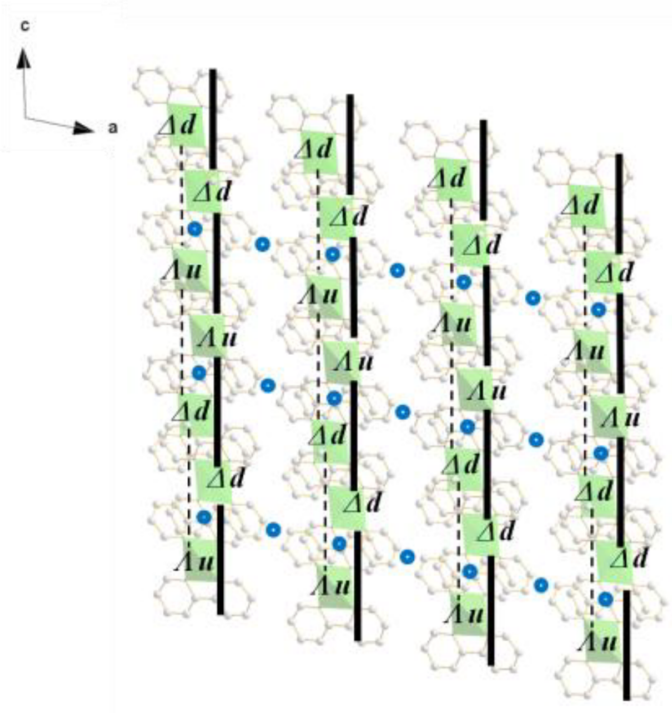

Figure 5. Representation of the layer stacking along the $b$ axis for (a) $\left[\mathrm{Cu}\left(\mathrm{H}_{2} \mathrm{O}\right)(\mathrm{bpy})_{2}\right]_{2}\left[\mathrm{HfF}_{6}\right]_{2} \cdot 3 \mathrm{H}_{2} \mathrm{O}$ and $\left.(\mathrm{b})\left[\mathrm{Cu}\left(\mathrm{H}_{2} \mathrm{O}\right)(\mathrm{bpy})_{2}\right)\right]\left[\mathrm{BF}_{4}\right]_{2}$. Blue circles and dotted lines represent inversion centers and glide planes, respectively. Layers translate along the $b$ axis in the $\left[\mathrm{Cu}\left(\mathrm{H}_{2} \mathrm{O}\right)(\mathrm{bpy})_{2}\right]_{2}\left[\mathrm{HfF}_{6}\right]_{2} \cdot 3 \mathrm{H}_{2} \mathrm{O}$ structure and contribute to the absence of inversion centers.

containing a mirror plane as the unique improper operation. For this reason, relating the left- and right-handed enantiomers with only mirror planes (or glide planes) is a sufficient condition to have polarity in the solid state.

The two structures discussed in this article also show that racemic layered compounds are of interest in the design of polar materials. The layers of right- and left-handed enantiomers can be symmetrically related by only glide planes according to the specific arrangement or/and translation of layers. The charge and size of $\left[\mathrm{HfF}_{6}\right]^{2-}$ and $\left[\mathrm{BF}_{4}\right]^{-}$anions play an important role in the rearrangement and translation of the

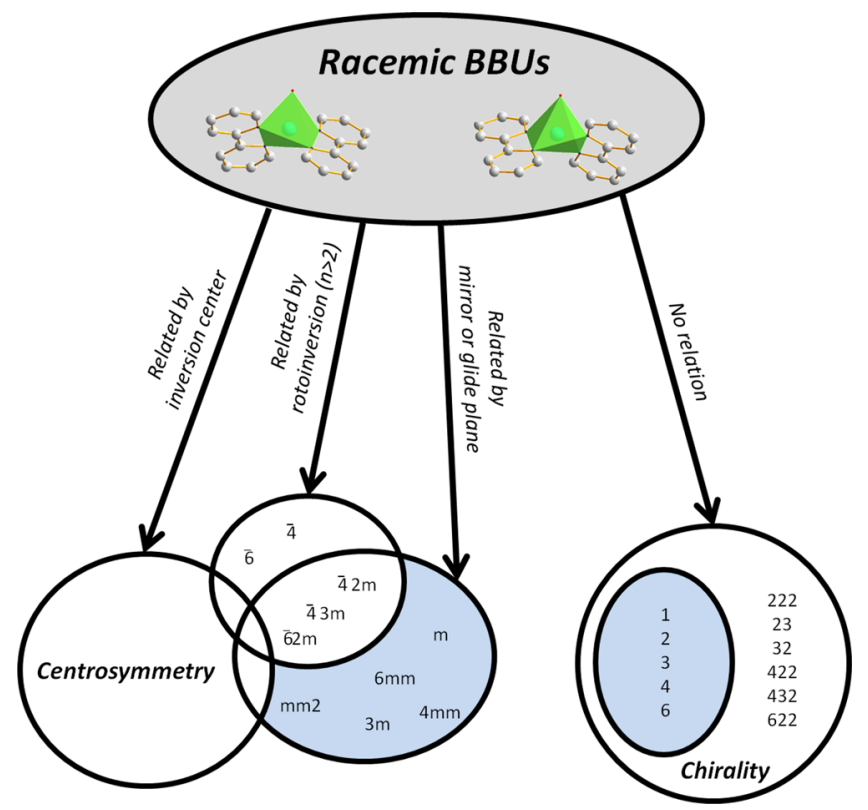

Figure 6. Noncentrosymmetric crystal classes targeted in the solid state from a racemic mixture of left- and right-handed BBUs. Groups of polar crystal classes are represented in blue. The structure can be centrosymmetric if left- and right-handed enantiomers are related by an inversion center. The structure is noncentrosymmetric if left- and right-handed enantiomers are related by rotoinversion, a mirror plane, or/and a glide plane instead of an inversion center. If left- and righthanded enantiomers are related only by a mirror or glide plane, the structure must be polar.

layers in $\left[\mathrm{Cu}\left(\mathrm{H}_{2} \mathrm{O}\right)(\text { bpy })_{2}\right]_{2}\left[\mathrm{HfF}_{6}\right]_{2} \cdot 3 \mathrm{H}_{2} \mathrm{O}$ and $\left[\mathrm{Cu}\left(\mathrm{H}_{2} \mathrm{O}\right)\right.$ $\left.\left.(\mathrm{bpy})_{2}\right)\right]\left[\mathrm{BF}_{4}\right]_{2}$ through the presence or absence of extended hydrogen-bonding networks.

\section{CONCLUSIONS}

This article describes the relation between the improper symmetry operations relating left- and right-handed enantiomers and the centrosymmetry or noncentrosymmetry in the solid state. In the $\left[\mathrm{Cu}\left(\mathrm{H}_{2} \mathrm{O}\right)(\mathrm{bpy})_{2}\right]\left[\mathrm{BF}_{4}\right]_{2}$ centrosymmetric structure, $\Delta$ - and $\Lambda$ - $\left[\mathrm{Cu}\left(\mathrm{H}_{2} \mathrm{O}\right)(\mathrm{bpy})_{2}\right]^{2+}$ enantiomers of adjacent layers are related by an inversion center. In the $\left[\mathrm{Cu}\left(\mathrm{H}_{2} \mathrm{O}\right)(\mathrm{bpy})_{2}\right]_{2}\left[\mathrm{HfF}_{6}\right]_{2} \cdot 3 \mathrm{H}_{2} \mathrm{O}$ noncentrosymmetric structure, translations and new arrangement of the layers allow glide planes (instead of an inversion center) to relate $\left[\mathrm{Cu}\left(\mathrm{H}_{2} \mathrm{O}\right)\right.$ $\left.(\text { bpy })_{2}\right]^{2+}$ enantiomers of different handedness and lead to polar symmetry. The driving force of translations and the new arrangement of layers is the use of different anions (charge and/or size) and could also be imitated in other lamellar racemic compounds to create polarity. Relating enantiomers of left- and right-handedness with only mirror or glide planes is also a promising alternative route for engineering polarity in the solid state.

\section{ASSOCIATED CONTENT}

\section{S Supporting Information}

$\mathrm{X}$-ray crystallographic file in CIF format for compound $\left[\mathrm{Cu}\left(\mathrm{H}_{2} \mathrm{O}\right)(\mathrm{bpy})_{2}\right]_{2}\left[\mathrm{HfF}_{6}\right]_{2} \cdot 3 \mathrm{H}_{2} \mathrm{O}$, structure description, Figure $\mathrm{S} 1$. This material is available free of charge via the Internet at http://pubs.acs.org. 


\section{AUTHOR INFORMATION}

\section{Corresponding Author}

*E-mail: krp@northwestern.edu.

Notes

The authors declare no competing financial interest.

\section{ACKNOWLEDGMENTS}

This work was supported by funding from the National Science Foundation (Solid State Chemistry Award DMR-1005827). The single-crystal X-ray data were acquired at Northwestern University's Integrated Molecular Structure Education and Research Center (IMSERC). We additionally thank Amy Sarjeant and Charlotte Stern for discussions regarding the crystal structure.

\section{REFERENCES}

(1) Flack, H. D. Chiral and Achiral Crystal Structures. Helv. Chim. Acta 2003, 86 (4), 905-921.

(2) Morris, R. E.; Bu, X. Induction of chiral porous solids containing only achiral building blocks. Nat. Chem. 2010, 2, 353-361.

(3) Halasyamani, P. S.; Poeppelmeier, K. R. Noncentrosymmetric Oxides. Chem. Mater. 1998, 10 (10), 2753-2769.

(4) Maggard, P. A.; Stern, C. L.; Poeppelmeier, K. R. Understanding the Role of Helical Chains in the Formation of Noncentrosymmetric Solids. J. Am. Chem. Soc. 2001, 123 (31), 7742-7743.

(5) Maggard, P. A.; Kopf, A. L.; Stern, C. L.; Poeppelmeier, K. R.; Ok, K. M.; Halasyamani, P. S. From Linear Inorganic Chains to Helices: Chirality in the $\mathrm{M}(\mathrm{pyz})\left(\mathrm{H}_{2} \mathrm{O}\right)_{2} \mathrm{MoO}_{2} \mathrm{~F}_{4}(\mathrm{M}=\mathrm{Zn}, \mathrm{Cd})$ Compounds. Inorg. Chem. 2002, 41 (19), 4852-4858.

(6) Donakowski, M. D.; Gautier, R.; Yeon, J.; Moore, D. T.; Nino, J. C.; Halasyamani, P. S.; Poeppelmeier, K. R. The Role of Polar, Lambda-Shaped Building Units in Noncentrosymmetric Inorganic Structures. J. Am. Chem. Soc. 2012, 134 (18), 7679-7689.

(7) Gautier, R.; Donakowski, M. D.; Poeppelmeier, K. R. Orientational order of $\left[\mathrm{VOF}_{5}\right]^{2-}$ and $\left[\mathrm{NbOF}_{5}\right]^{2-}$ polar units in chains. J. Solid State Chem. 2012, 195 (0), 132-139.

(8) Gutnick, J. R.; Muller, E. A.; Narducci Sarjeant, A.; Norquist, A. J. $\left[\mathrm{C}_{5} \mathrm{H}_{14} \mathrm{~N}_{2}\right]\left[\left(\mathrm{MoO}_{3}\right)_{3}\left(\mathrm{SO}_{4}\right)\right] \cdot \mathrm{H}_{2} \mathrm{O}$ : Sulfated $\alpha$-Molybdena Chains. Inorg. Chem. 2004, 43 (21), 6528-6530.

(9) Muller, E. A.; Cannon, R. J.; Sarjeant, A. N.; Ok, K. M.; Halasyamani, P. S.; Norquist, A. J. Directed Synthesis of Noncentrosymmetric Molybdates. Cryst. Growth Des. 2005, 5 (5), 19131917.

(10) Veltman, T. R.; Stover, A. K.; Narducci Sarjeant, A.; Ok, K. M.; Halasyamani, P. S.; Norquist, A. J. Directed Synthesis of Noncentrosymmetric Molybdates Using Composition Space Analysis. Inorg. Chem. 2006, 45 (14), 5529-5537.

(11) Hubbard, D. J.; Johnston, A. R.; Casalongue, H. S.; Sarjeant, A. N.; Norquist, A. J. Synthetic Approaches for Noncentrosymmetric Molybdates. Inorg. Chem. 2008, 47 (19), 8518-8525.

(12) Glor, E. C.; Blau, S. M.; Yeon, J.; Zeller, M.; Shiv Halasyamani, P.; Schrier, J.; Norquist, A. J. $\left[R-\mathrm{C}_{7} \mathrm{H}_{16} \mathrm{~N}_{2}\right]\left[\mathrm{V}_{2} \mathrm{Te}_{2} \mathrm{O}_{10}\right]$ and $[S$ $\left.\mathrm{C}_{7} \mathrm{H}_{16} \mathrm{~N}_{2}\right]\left[\mathrm{V}_{2} \mathrm{Te}_{2} \mathrm{O}_{10}\right]$; new polar templated vanadium tellurite enantiomers. J. Solid State Chem. 2011, 184 (6), 1445-1450.

(13) Gautier, R.; Poeppelmeier, K. R. Preservation of Chirality and Polarity between Chiral and Polar Building Units in the Solid State. Inorg. Chem. 2012, 51 (20), 10613-10618.

(14) Dalhus, B.; Gorbitz, C. H. Non-centrosymmetric racemates: Space-group frequencies and conformational similarities between crystallographically independent molecules. Acta Crystallogr. B 2000, 56 (4), 715-719.

(15) Fabian, L.; Brock, C. P. A list of organic kryptoracemates. Acta Crystallogr. B 2010, 66 (1), 94-103.

(16) SAINT-Plus, version 6.02A; Bruker Analytical X-ray Instruments: Madison, WI, USA, 2000.

(17) Sheldrick, G. M. SADABS; University of Göttingen: Göttingen, Germany, 2002.
(18) Altomare, A.; Burla, M. C.; Camalli, M.; Cascarano, G. L.; Giacovazzo, C.; Guagliardi, A.; Moliterni, A. G. G.; Polidori, G.; Spagna, R. SIR97: A new tool for crystal structure determination and refinement. J. Appl. Crystallogr. 1999, 32 (1), 115-119.

(19) Sheldrick, G. A short history of SHELX. Acta Crystallogr. A 2008, 64 (1), 112-122.

(20) Spek, A. L. PLATON; Utrecht University: Utrecht, The Netherlands, 2001.

(21) Yu, M.-M.; Zhang, Y.-N.; Wei, L.-H. Aquabis (2,2'-bipyridine- $\kappa^{2}$ $\left.N, N^{\prime}\right)$ copper(II) bis(tetrafluoridoborate). Acta Crystallogr. E 2007, 63 (9), $\mathrm{m} 2380$.

(22) Knof, U.; von Zelewsky, A. Predetermined Chirality at Metal Centers. Angew. Chem., Int. Ed. 1999, 38 (3), 302-322.

(23) Hunter, C. A.; Sanders, J. K. M. The nature of $\pi-\pi$ interactions. J. Am. Chem. Soc. 1990, 112 (14), 5525-5534.

(24) Welk, M. E.; Norquist, A. J.; Arnold, F. P.; Stern, C. L.; Poeppelmeier, K. R. Out-of-Center Distortions in $\mathrm{d}^{0}$ Transition Metal Oxide Fluoride Anions. Inorg. Chem. 2002, 41 (20), 5119-5125.

(25) Hahn, T., Ed. International Tables for Crystallography, 1st ed.; Kluwer Academic Publishers: Dordrecht, The Netherlands, 1983. 